\title{
Effectiveness of knowledge-based multinational management on global supply chain excellence
}

\author{
Sang-Yoon Lee*, Young-Ki Kim** and Seong-Tae Kim***
}

\begin{abstract}
In current business management, knowledge is considered to be a strategic resource that can strengthen an organization's competitiveness. Today, under the process of continuous globalization, almost all companies are rapidly exposed to global competition regardless of their scale or type of business. However, multinational management is very complicated and uncertain and it is hard for multinationals to effectively coordinate and manage their global value chains. In light of this, the utility of multinational management based on knowledge is increased. The present study examines multinational firms' knowledge management systems, knowledge creation processes and global supply chain performance and attempts to reveal any significant linkages between these latent variables. For this research interest, we proposed 18 items to measure four types of knowledge creation processes (SECI) designed by Nonaka (1994) and revised by authors considering the global business environment, in particular involving the global supply chain management concept. Utilizing the confirmed SECI model, 128 sample companies were classified into four groups according to the levels of their knowledge creation processes. The empirical results of this study reveal important linkages between a multinational firm's knowledge management system and knowledge creation process, as well as between its knowledge creation process and global supply chain management performance. In particular, the current work suggests that the creation and conversion of tacit knowledge as well as explicit knowledge can be effectively supported by information and communication technology.
\end{abstract}

Key words: Multinational management, Knowledge management, Knowledge creation process (SECI), Global supply chain management, Confirmatory factor analysis, Cluster analysis, ANOVA

* Associate Professor, Graduate School of Logistics, Inha University, 253 Yonghyun-Dong, Nam-Gu, Incheon, 402-751, Korea, Corresponding author, E-mail: sylee@inha.ac.kr

** Graduate Student, Graduate School of Logistics, Inha University, 253 Yonghyun-Dong, Nam-Gu, Incheon, 402-751, Incheon, Korea, E-mail: logismarketing@gmail.com

*** Graduate Student, Graduate School of Logistics, Inha University, 253 Yonghyun-Dong, Nam-Gu, Incheon, 402-751, Incheon, Korea, E-mail: kimnalda@naver.com

This work was supported by Inha University research grant. 


\section{Introduction:}

In the context of current business management, knowledge is considered to be a strategic resource that can strengthen an organization's competitiveness. Nonaka (1994) asserts that knowledge is a critical resource for a sustainable competitive advantage, especially in uncertain economic circumstances. Knowledge management is a process that converts data and materials into highly valued knowledge. Demarest (1997) defines knowledge management as a systematic program or a process that can strengthen and optimize knowledge economies. On the other hand, in a situation of continuous globalization, almost all companies are rapidly exposed to global competition regardless of their scale and type of business. In particular, the World Trade Organization (WTO) system launched in 1995 has continuously stimulated borderless production and trade activities through the abolition of trade and non-trade barriers and the liberalization of Foreign Direct Investment (FDI). As a matter of fact, contemporary multinational management involves numerous medium and small sized firms. For instance, Lubricating Systems, a US manufacturer of lubricating fluids for machine tools, employs 25 people and generates sales of $\$ 6.5$ million, of which more than $\$ 2$ million are generated by exports. This small company has also engaged in foreign direct investment in Germany to serve the European market (Hill, 2009). In short, the globalization trend provides all firms with new business opportunities.

However, multinational management is very complicated and uncertain, with the result that it is hard for multinationals to effectively coordinate and manage their global value chains. In light of this, the utility of knowledge-based multinational management is increased. If explicit and tacit knowledge created through global value chains could be effectively collected, accumulated, shared and transferred, a company's global management may create greater outcomes and competitiveness. The present research focuses on the following two issues: first, how global firms design and manage their global management systems and networks with regard to knowledge; and second, what the management implications of effective knowledge creation and conversion are on a company. In order to answer to these questions, this paper attempts to classify multinational firms according to the relative levels of their knowledge creation processes, adopting the SECI (socialization, externalization, combination and internalization) model suggested by Nonaka (1994) and examines the heterogeneity among them in terms of knowledge management system and global supply chain management performance. 


\section{Literature Review}

\subsection{Knowledge and Knowledge Management}

Knowledge can be distinguished from information: the latter is related with the facts of the real world and needs to be translated, while the former can be understood as the ability to interpret information and to transform it into new knowledge (Davenport and Prusak, 1998). In general, knowledge can be classified as either explicit or tacit knowledge (Polanyi, 1967; Nonaka \& Takeuchi, 1995). Explicit knowledge is formulated from the rationalization of information and can be codified in the form of formulas, designs and reports and can be digitalized. Therefore, explicit knowledge can be transferred utilizing information and communication technology (ICT). In contrast, tacit knowledge is connected with ideas, perceptions and experience. Because tacit knowledge can be obtained through long-term practice and experience, it is difficult for the organization to digitalize and transfer its tacit knowledge.

According to Davenport et al. (1996), knowledge management (KM) has different goals such as finding and storing existing knowledge, creating fresh knowledge, or assembling knowledge created externally. Millar et al. (1997) proposed that knowledge management involves the four interdependent activities of knowledge identification, codification, interchange and production. This kind of process-based view of knowledge management was also adopted in the knowledge creation model proposed by Nonaka (1994), who established four sub-processes involved in knowledge creation, namely socialization, externalization, combination and internalization (SECI). Socialization (from tacit to tacit knowledge) refers to the process of sharing experience and thereby creating tacit knowledge, which needs informal networks to exchange practical experience and know-how between partners. Externalization (from tacit to explicit knowledge) involves the process of rationalizing tacit knowledge and articulating it into explicit concepts and formal models. Combination (from explicit to explicit knowledge) refers to the process of creating new explicit knowledge by merging, categorizing and synthesizing existing explicit knowledge. Finally, internalization (from explicit to tacit knowledge) denotes the process of converting an organization's explicit knowledge into individual and group-level tacit knowledge. Nonaka (1994, p. 14) asserted that, "Organizational knowledge is created through a continuous dialogue between tacit and explicit knowledge."

Regarding the efficacy of knowledge management, Drucker (1993) explained that knowledge is a strategic resource which will have a greater impact than physical capital in the future. According to Nonaka (1994), knowledge is the sole source of sustainable 
competitiveness for the firm in the context of economic uncertainty. In order to effectively respond to the changing market, evolving technology and emerging competitors, the firm should continuously create new knowledge. In this regards, Hendricks and Vriens (1999) posited that a firm's knowledge assets could provide the firm with competitive advantages supporting sustainable growth. It should be noted that many researchers have emphasized the importance of tacit knowledge because this sort of knowledge can be developed through unique organizational processes, making it difficult for competitors to imitate and distinguishing companies from their competitors (Nelson \& Winter, 1982; Hamel and Prahalad ,1994; Teece et al., 1997).

Indeed, there is empirical research to suggest that firms conducting knowledge management perform better than those among their competitors which have not implemented it. In terms of financial performance, for instance, it has been shown that knowledge management stimulates cost reductions and generates increased sales volumes, profits and market share (Lee and Choi, 2003; Choi et al., 2008). With respect to non-financial performance, knowledge management has additionally been found to exert a positive influence on productivity, employee satisfaction and customer service (Knapp, 1998; Plessis, 2005; Yang et al,. 2009).

\subsection{Knowledge Management System}

In order to pursue effective flows of information and knowledge among business units and organizations, a knowledge management system should be comprehensively constructed in advance, comprising the rules and conditions dealing with data and information between the organizations as well as within the firm, together with software solutions enabling participants to access the sources and obtain information as needed. In particular, a compensation procedure should be included in the knowledge management system to identify and transfer scarce knowledge created by local units since knowledge sources may worry about losing their ownership or privilege position or power and be reluctant to share their knowledge (Szulanski, 1996: 31). In particular, tacit knowledge requires much time to be embodied; the owners of this knowledge are unlikely to share their knowledge without sufficient compensation (Leonard and Sensiper, 1998: 123).

Meanwhile, information and communication technology (ICT) has been recognized as a critical tool for knowledge management, which can convert data into timely information, support collaboration between organizations and enable users to access and share knowledge. Evidently, ICT is used in regular trading for transmitting trade documents such as orders, invoices and stock levels. This system requires a full set of pre-definition on the 
codified data and on the rules for data interpretation which is mainly related to the combination of knowledge in the SECI model. ICT may reduce times and human errors in the knowledge exchange and efficiently coordinate different firms and units regardless of their locations. However, some researchers (e.g. Antonelli, 1997; Nonaka \& Takeuchi, 1995; Stewart, 1997) have pointed to a lack of economic linkage between ICT investment and knowledge management. According to them, information technology has focused too much on explicit knowledge and de-emphasized the role of tacit knowledge which may generate core competencies in companies. Counter to this view, other authors (e.g. Johannessen et al., 2001) have attempted to identify the role of ICT connecting the organization's tacit knowledge with its innovation and competitiveness. In particular, Bolisani and Scarso (1999) have provided industry cases explaining how ICT can support knowledge creation and transmission in terms of socialization, externalization and internalization, as well as combination. Similarly, Vaccaro et al. (2009) explained that the intensive exploitation of information and communication technology had led to new forms of knowledge creation. According to them, the capability of virtual technology can support the creation and transmission of new knowledge at both the individual and organizational level.

\subsection{Multinational Companies and Knowledge Management}

Multinational companies have re-designed their global production and distribution networks across the globe in pursuit of cost reductions in sourcing, manufacturing, distribution and tax incentives. The main global management players consist of about 79 thousand multinational firms operating approximately 790 thousand overseas branches employing 8.2 million laborers, which together recorded 31 trillion dollars of sales value and 15 trillion dollars of FDI stock and accounted for 11\% of world GDP in 2007 (Hill, 2009).

Traditionally, one of the critical issues facing multinational firms was the selection of strategic positions in order to effectively respond to two fundamental pressures: cost reduction and local responsiveness. In the past, it was recommended that a firm should choose either cost reduction or localization as a strategy (Porter, 1980, 1985). However, in recent years, it has been proposed that companies should pursue both positions, specifically a transnational management strategy. It should be noted that the core idea of transnational management does not require a physical combination of the cost reduction strategy utilizing locational advantage or experience effect with the localization strategy providing customized goods and services in a specific region. Bartlett and Ghoshal (1989, cited in 
Hill, 2009) argued that under conditions of global competition, firms must do all they can to respond to pressures for cost reductions and local responsiveness. According to them, in the modern multinational enterprise, core competencies do not remain in the mother firm but can be developed in any of its worldwide operations. Therefore, multinational firms should make sure that information and knowledge can move freely not only between their headquarters and foreign subsidiaries, but also between foreign subsidiaries. In consequence, the effective exchange of explicit and tacit knowledge through a global network allows the multinational firm to utilize the most recent skills, technologies and innovative ideas created from its business units over the globe and thus improve its competitiveness.

\section{Research Methodology}

\subsection{Survey Instrument Development}

In the present research, seven constructs are proposed to explore critical differences between multinational organizations in terms of knowledge management systems, knowledge creation processes and global supply chain management performance. First, ICT infrastructure and KM rules are considered to be the essential components of the knowledge management system as suggested in the literature by Bolisani and Scarso (1999), Sher and Lee (2004) and Hsieh et al. (2009). ICT infrastructure is measured using 6 items and knowledge management rules have 7 items, as shown in Table 1.

\section{Table 1.}

Information and communication technology and knowledge management rules

\begin{tabular}{c|l}
\hline Construct & \multicolumn{1}{c}{ Measurement } \\
\hline $\begin{array}{c}\text { Information and } \\
\text { Communication } \\
\text { Technology } \\
\text { Infrastructure }\end{array}$ & $\begin{array}{l}\text { ICT1: Our organization provides an enterprise portal site for foreign customers. } \\
\text { ICTd classify obtained data from internal and external organizations on its global } \\
\text { network. } \\
\text { ICT) }\end{array}$ \\
$\begin{array}{l}\text { ICT: Our organization has established and operates a database which can store } \\
\text { recording. }\end{array}$ \\
\hline
\end{tabular}




\begin{tabular}{c|l}
\hline Construct & \multicolumn{1}{c}{ Measurement } \\
\hline Knowledge & $\begin{array}{l}\text { ICT4: Our organization has established and operates an integrated information } \\
\text { system which can transfer information to the internal and external organizations } \\
\text { (e.g. suppliers and customers) on its global network. } \\
\text { ICT5: Our organization has established and operates a video conference system } \\
\text { and groupware system for the meetings and discussions between the } \\
\text { organizations on its global network. }\end{array}$ \\
$\begin{array}{l}\text { ICT6: Our organization has established and operates an internal and external } \\
\text { expert network for the specific and effective utilization of required information } \\
\text { and knowledge. }\end{array}$ & $\begin{array}{l}\text { KMR1: Our organization operates related regulations and processes to construct } \\
\text { and maintain yellow pages classifying the web-sites according to their business } \\
\text { types. } \\
\text { KMR2: Our organization operates related regulations and processes to construct } \\
\text { and maintain a knowledge map. } \\
\text { KMR3: Our organization operates related regulations and processes to acquire } \\
\text { internal knowledge to improve the quality and quantity of the knowledge base } \\
\text { (e.g. compensation to internal knowledge creators or evaluation for internal } \\
\text { knowledge learning performance). } \\
\text { KMR4: Our organization operates related regulations and processes to acquire } \\
\text { external knowledge to improve the quality and quantity of the knowledge base } \\
\text { (e.g. compensation to external knowledge creators or evaluation for external } \\
\text { knowledge learning performance). } \\
\text { KMR5: Our organization has a culture and/or orientation to share knowledge } \\
\text { among members. } \\
\text { KMR6: Our organization has related regulations and processes to manage, } \\
\text { control and preserve critical knowledge which could be shared with external } \\
\text { organizations. } \\
\text { KMR7: Our organization operates related regulations and processes to facilitate } \\
\text { the active participation of members in knowledge learning projects and sharing } \\
\text { the results. }\end{array}$ \\
\hline and
\end{tabular}

Next, regarding the knowledge creation process, Nonaka's SECI model was employed. The measurements had been chosen from various studies such as Bolisani and Scarso (1999), Holsapple and Singh (2001), Sher and Lee (2004), Hsieh et al. (2009) and Vaccaro et al. (2009) and were carefully revised reflecting the global management environment based on the applications of information technology. In addition, global supply chain management issues are involved in the knowledge creation process. For instance, in the 
construct of socialization, the item "Our organization is able to establish more executable and/or unique plans by exchanging, compromising and improving tacit knowledge interactively among the persons concerned through the Internet at the stages of developing multinational strategies such as foreign direct investment or designing global supply chain" is related to the global supply chain management issue. A total of 18 items are utilized to measure knowledge creation and conversion process for multinational management firms as presented in Table 2.

\section{Table 2.}

Knowledge creation process

\begin{tabular}{|c|c|}
\hline Construct & Measurement \\
\hline $\begin{array}{l}\text { Socialization } \\
\qquad(5)\end{array}$ & $\begin{array}{l}\text { S1: Our organization cumulates tacit knowledge (knowledge difficult to express } \\
\text { in terms of language or letters) or experience including high degree of } \\
\text { professionalism and skilled capability in the forms of image files and picture } \\
\text { recording data. } \\
\text { S2: Our organization implements a mentoring program to transfer tacit } \\
\text { knowledge by utilizing on-line media. } \\
\text { S3: In our organization, various 'community of practice' activities are } \\
\text { implemented through the Internet and members at distant places can effectively } \\
\text { participate in the activities. } \\
\text { S4: Our organization is able to establish more executable and/or unique plans } \\
\text { by exchanging, compromising and improving tacit knowledge interactively } \\
\text { among the persons concerned through the Internet at the stages of developing } \\
\text { multinational strategies such as foreign direct investment or designing global } \\
\text { supply chain. } \\
\text { S5: Our organization is able to create new tacit knowledge by sharing, } \\
\text { exchanging, transferring and combining tacit knowledge through the on-line } \\
\text { network. }\end{array}$ \\
\hline $\begin{array}{c}\text { Extemalization } \\
\text { (5) }\end{array}$ & $\begin{array}{l}\text { E1: Our organization is able to transform multinational management related } \\
\text { knowledge obtained by individuals and/or organizations into the form of } \\
\text { documents such as reports and/or manuals by utilizing information technology. } \\
\text { E2: In our organization, digitalization of documents has been facilitated by } \\
\text { effective utilization of information technology. } \\
\text { E3: In our organization, tacit knowledge is able to be realized at practical sites } \\
\text { through information technology (e.g. by combining information technology and } \\
\text { CAD system, a product design can be transferred to the machines or facilities to } \\
\text { produce the good). } \\
\text { E4: Our organization has reduced dependence on specific persons for obtaining } \\
\text { and utilizing knowledge by information technology. }\end{array}$ \\
\hline
\end{tabular}




\begin{tabular}{c|l}
\hline Construct & \multicolumn{1}{c}{ Measurement } \\
\hline Combination & $\begin{array}{l}\text { E5: Our organization documents tacit knowledge shared with global supply } \\
\text { chain partners or customers if that knowledge is able to be documented } \\
\text { management by collecting technical information and documents by the } \\
\text { utilization of information technology. }\end{array}$ \\
$\begin{array}{c}\text { C2: Our organization members are able to identify persons or divisions related } \\
\text { with necessary information and/or knowledge by the utilization of information } \\
\text { technology. }\end{array}$ & $\begin{array}{l}\text { C3: Our organization members are able to effectively synthesize and } \\
\text { re-combine the digitalized papers and documents by the utilization of } \\
\text { information technology. } \\
\text { C4: Through information technology, our organization is able to create new } \\
\text { knowledge by facilitating transfer, exchange and synthesis of documented } \\
\text { information and knowledge and also document this new knowledge. }\end{array}$ \\
\hline Internalization & $\begin{array}{l}\text { I1: In our organization, through information technology, the members or } \\
\text { divisions are able to acquire formalized habits or procedures in the form of } \\
\text { documents. } \\
\text { I2: Our organization is able to create new tacit knowledge through the process } \\
\text { of knowledge internalization. } \\
\text { I3: Through information technology, company members, who don't have } \\
\text { expertise and/or skills, are able to utilize complicated explicit knowledge in } \\
\text { their place of work (e.g. A local A/S center utilizes a CD-ROM designed to } \\
\text { provide relevant information for identifying a required part when a precision } \\
\text { machine needs to have that part changed). } \\
\text { I4: Through information technology, our organization provides job training to } \\
\text { global supply chain partners and/or help the customers learn how to use our } \\
\text { products. }\end{array}$ \\
\hline (4)
\end{tabular}

Finally, the latent construct of global SCM performance includes eight items: global sourcing, global production, international transportation, international distribution, demand forecasting and planning, inventory management, supply chain integration and reverse logistics in the global context. 
Table 3.

Global supply chain management performance

\begin{tabular}{c|l}
\hline Construct & \multicolumn{1}{c}{ Measurement } \\
\hline Global & GSCP1: Global sourcing \\
Supply Chain & GSCP2: Global production \\
Performance & GSCP3: International transportation \\
$\mathbf{( 8 )}$ & GSCP4: International distribution and after sales \\
& GSCP5: Demand forecasting and planning in foreign markets \\
& GSCP6: Inventory management in foreign markets \\
& GSCP7: Global supply chain integration \\
& GSCP8: Reverse logistics in foreign markets \\
\hline
\end{tabular}

\subsection{Survey process}

In order to examine the current positions of multinational firms in terms of knowledge management and global SCM performance, a questionnaire survey process was conducted. First, a questionnaire was designed and reviewed by experts (three academics and three practitioners) regarding the relevance and clarification of the wording in the measurement items. Through this process, several changes in wording were made. In addition, some questions regarding the descriptive information on the respondents and their companies were changed into multiple choice forms. This pilot test helped to ensure content validity, which means that the scale items may include theoretical and practical considerations (Churchill, 1979). The levels of knowledge management system, knowledge creation process and global SCM performance of multinational firms were measured using a five-point Likert scale (1: strongly disagree, 2: disagree, 3: neutral, 4: agree, 5: strongly agree) in response to the following request: "Please assess to what extent you agree or disagree with the following questions in the context of your firm's knowledge management and global SCM performance."

Our target samples were Korean and non-Korean multinational firms including manufacturers, logistics service providers and retailers and wholesalers, which were selected from the company list of the Korea Chamber of Commerce and Industry and the member list of the Korea Integrated Logistics Association. In addition, the company profiles accumulated in the Graduate School of Logistics at Inha University have been utilized. A total of 500 firms were selected from those pools and related persons were contacted through e-mail and telephone calls. 


\section{Empirical Results}

\subsection{Data and Sample Description}

A total of 146 answered questionnaires were returned (the respondent rate was 29.2\%), among which 18 questionnaires were excluded due to duplicated replies from the same companies and unreliable answering patterns such as selecting only one choice across all the questions. With the remaining 128 questionnaires, a t-test was conducted to check for non-respondent bias. The result showed that there was no statistically significant difference in the mean values of the 39 items between the early response group (first quartile of respondents) and the late response group (last quartile of respondents), indicating that non-response bias was not a major problem in this study (Armstrong and Overton, 1977). Among the sample companies, 82 are Korean multinational firms and the other 46 are non-Korean firms. The headquarters of the non-Korean multinational companies are located in Asia (Japan, Hong Kong China, Taiwan and Singapore), North America and Europe (U.K., France, Germany, Switzerland, the Netherlands and Russia). Of these, 63 are manufacturing firms, 43 are logistics service providers and 22 are wholesaler/ retailer /trading firms.

Regarding the companies, 44 of the Korean firms have a history of more than 30 years and 9 companies have been operating for less than 10 years, while 23 of the non-Korean firms have a history of more than 30 years and only 2 companies have less than 10 years. Concerning sales volume in 2009, 57\% of the Korean firms recorded less than 1 billion USD while $70 \%$ of the non-Korean firms recorded more than 10 billion USD. The mean of respondents' work experience was about 11 years and the mean of the job grade was around point 5, given a 9 point Likert scale where point 1 is clerk and point 9 is CEO, which corresponded to a general manager's position. Thus, the respondents of this research can be assumed to possess the necessary information to assess their firms' knowledge management and multinational management performance. Descriptive statistics are shown in the Appendix.

\subsection{Measurement Model: Validity and Reliability}

Confirmative factor analysis (CFA) was used to assess the unidimensionality and convergent validity, discriminant validity and reliability of the SECI model designed to 
measure multinationals' knowledge creation and conversion processes. The CFA results are shown in Table 4: the chi-square goodness-of-fit statistics were statistically significant, indicating that the rejection of the null hypothesis and poor model fit. However, the comparative fit index (CFI; > 0.90), the Tucker and Lewis Index (TLI; > 0.90) and the root mean square error of approximation (RMSEA; < 0.10) indicate an acceptable fit at a commonly recommended benchmark (Steiger, 1990; Hair et al., 2010).

Unidimensionality and convergent validity were assessed by the fit indices and the significance of t-value. As Table 4 reveals, various fit statistics show that the measurement model fits the data reasonably well. Moreover, the test result shows that the item loadings for each factor are significant $(p<0.01)$. Thus, the unidimensionality and convergent validity of the measurement model were said to be certified (Anderson and Gerbing, 1988). Discriminant validity was assessed by performing a chi-square difference test on the values that were obtained from the constrained (i.e. the correlation between two constructs is fixed as equal to one) and unconstrained models (Bagozzi and Phillips, 1982). The result revealed that the unconstrained models were significantly better than the constrained model for all, indicating that the significant results of the chi-square difference test confirm the discriminant validity of the theoretical constructs (Bagozzi and Phillips, 1982). We also assessed the reliability of a construct by evaluating the construct reliability (CR) and the average variance extracted (AVE). As Table 4 presents, all the CR and AVE values of the latent variables were greater than the minimum required value, 0.7 and 0.5 respectively, indicating that the reliability for the measurement model were said to be certified (Anderson and Gerbing, 1988).

\section{Table 4.}

Results of confirmatory factor analysis (CFA)

\begin{tabular}{ccccccc}
\hline Model & Construct & $\begin{array}{c}\text { Num. of } \\
\text { Items }\end{array}$ & $\begin{array}{c}\text { Stand. loading } \\
(\text { range })^{\mathrm{a}}\end{array}$ & $\begin{array}{c}\text { C' alpha } \\
(\mathrm{min} .>0.70)\end{array}$ & $\begin{array}{c}\text { CR } \\
(\min .>0.70)\end{array}$ & $\begin{array}{c}\text { AVE } \\
(\min .>0.50)\end{array}$ \\
\hline SECI & Socialization & 5 & $0.77-0.89$ & 0.92 & 0.89 & 0.63 \\
& Externalization & 5 & $0.75-0.86$ & 0.89 & 0.88 & 0.60 \\
& Combination & 4 & $0.76-0.89$ & 0.90 & 0.89 & 0.68 \\
& Internalization & 4 & $0.78-0.85$ & 0.89 & 0.89 & 0.66 \\
\hline
\end{tabular}

Note: $x^{2}=205.838, \mathrm{df}=127, p=0.000, x^{2} / \mathrm{df}=1.62, \mathrm{CFI}=0.959$, TLI $=0.951, \mathrm{RMSEA}=0.070$; ${ }^{\mathrm{a}} \mathrm{All}$ standardized factor loadings are significant at the $p<0.01$ level. 


\section{Table 5.}

Result of Pearson correlation analysis $(\mathrm{n}=128)$

\begin{tabular}{c|cccc}
\hline & \multicolumn{4}{|c}{ Correlations between constructs } \\
\cline { 2 - 5 } & S & E & C & I \\
\hline Socialization (S) & 1 & & & \\
Externalization (E) & 0.75 & 1 & 1 & 1 \\
Combination (C) & 0.78 & 0.73 & 0.81 & 1 \\
Internalization (I) & 0.79 & 0.77 & & \\
\hline
\end{tabular}

Note: All correlations are significant at the $p<0.01$ level.

\subsection{Classification of the SECI Model}

Based on the empirical evidence of construct reliability and validity, a cluster analysis was performed to determine if there are different types of multinational firms according to their levels of knowledge creation process in terms of socialization, externalization, combination and internalization. In applying cluster analysis to the sampled 128 firms, we used a two-step process as follows (Hair et al., 2010). In the first step, we employed the hierarchical procedure using Ward's method. In this procedure, an agglomeration coefficient, which displays the squared Euclidean distances between each case, was used to preliminary set the number of clusters. As shown in Table 6, a percentage change in the agglomeration coefficient reveals a great increase in a two-cluster solution ((436.90 $201.44) / 201.44=1.169)$. This is followed by a four-cluster solution, which yields a proportionate increase of 35.4 percent $((158.97$ - 117.45) / $117.45=0.354)$. According to Hair et al. (2010), however, a two-cluster solution mostly shows the largest increase and there must need strong theoretical reasoning in order to support this stage; it is thus recommended that researchers should avoid selecting the two-cluster solution as the best. Given the discussion as well as findings shown in the table, we concluded that the appropriate number of clusters is four. 
Table 6.

Analysis of agglomeration coefficients

\begin{tabular}{c|c|c|c}
\hline $\begin{array}{c}\text { Number of clusters after } \\
\text { combining }\end{array}$ & $\begin{array}{c}\text { Agglomeration } \\
\text { coefficient }\end{array}$ & $\begin{array}{c}\text { Difference in } \\
\text { coefficient }\end{array}$ & $\begin{array}{c}\text { Percentage change in } \\
\text { coefficient to next stage }\end{array}$ \\
\hline 8 & 77.29 & 6.05 & $7.8 \%$ \\
7 & 83.34 & 6.66 & $8.0 \%$ \\
6 & 90.00 & 9.20 & $10.2 \%$ \\
5 & 99.20 & 18.25 & $18.4 \%$ \\
4 & 117.45 & 41.52 & $35.4 \%$ \\
3 & 158.97 & 42.47 & $26.7 \%$ \\
2 & 201.44 & 235.46 & $116.9 \%$ \\
1 & 436.90 & & \\
\hline
\end{tabular}

To determine the final cluster solutions, we then utilized the nonhierarchical procedure (i.e. K-mean cluster analysis) on the basis of the range of preliminary solutions as suggested by the first stage. As shown in Table 7, the 128 Korean logistics firms were categorized into four clusters: 48 in cluster 1, 16 in cluster 2, 22 in cluster 3 and 42 in cluster 4. Analysis of variance (ANOVA) and a Scheffe test were used to discover whether the mean values of the SECI dimensions were significantly different among the four groups. The test results indicate that there are significant differences among the groups at $\mathrm{p}$ $<0.001$ and each group at $p<0.05$, respectively, indicating that each group differs clearly.

Table 7.

One-way ANOVA and cluster means on SECI model

\begin{tabular}{|c|c|c|c|c|c|}
\hline \multirow[t]{2}{*}{ Factor } & \multicolumn{4}{|c|}{ SECI Cluster } & \multirow[t]{2}{*}{ F } \\
\hline & $1(n=48)$ & $2(n=16)$ & $3(n=22)$ & $4(n=42)$ & \\
\hline SECI & $4.38(2,3,4)$ & $3.61(1,3,4)$ & $1.76(1,2,4)$ & $1.72(1,2,3)$ & $382.52 * * *$ \\
\hline Socialization (S) & $4.38(2,3,4)$ & $3.35(1,3,4)$ & $2.37(1,2,4)$ & $1.42(1,2,3)$ & $166.96^{* * *}$ \\
\hline Externalization (E) & $4.33(2,3,4)$ & $3.72(1,3,4)$ & $2.78(1,2,4)$ & $1.95(1,2,3)$ & $112.13 * * *$ \\
\hline Combination (C) & $4.63(2,3,4)$ & $3.82(1,3,4)$ & $3.11(1,2,4)$ & $1.92(1,2,3)$ & $120.56^{* * *}$ \\
\hline Internalization (I) & $4.20(2,3,4)$ & $3.55(1,3,4)$ & $2.79(1,2,4)$ & $1.60(1,2,3)$ & $120.03 * * *$ \\
\hline
\end{tabular}

Note: Numbers in parentheses indicate group number from which the group is different at the significant level 0.05 (Scheffe Test). ${ }^{*} p<0.05 ;{ }^{* *} p<0.01 ;{ }^{* * *} p<0.001$ 
The first cluster accounts for 37.5 percent of the sample, with the mean values of 4.38 , $4.33,4.63$ and 4.20, respectively. This indicates that multinationals in this group have the highest level of knowledge process in terms of SECI in their international businesses. We thus labeled cluster 1 as SECI leaders. This is followed by cluster 2, with 12.2 percent of the sample with a mean value for the four factors (i.e. S, E, C and I) of 3.61 and cluster 3, with 17.2 percent of the sample with the mean value of 2.76 . We labeled cluster 2 as SECI fast followers and cluster 3 as SECI slow followers respectively. The last cluster makes up 32.8 percent of the sample population, with the mean value of 1.72 which is the lowest level of SECI practices. We thus labeled cluster 4 as SECI laggards. One-way ANOVA suggests that the four groups are significantly different stages about their knowledge creation and conversion processes in terms of socialization, externalization, combination and internalization. SECI leaders recorded the highest scores while SECI laggards presented the lowest scores for the four types of knowledge creation paths.

\subsection{Comparison of Knowledge Management System and Performance among Clusters}

We attempted to compare the four groups in terms of knowledge management system and global SCM performance. Regarding knowledge management system first, the four groups revealed significant differences in information and communication technology and knowledge management rules across all the items. As shown in Table 8, each group is distinguished from the other groups; SECI leaders are on the highest position while SECI laggards show the lowest scores in knowledge management system, which may imply that the levels of firms' knowledge management system have positive connections with the four types of knowledge creation process. In other words, a well designed and implemented knowledge management system can be supportive for the firm to realize creation and conversion of tacit knowledge as well as explicit knowledge. 
Table 8.

One-way ANOVA of ICT and KMR differences among the four groups

\begin{tabular}{|c|c|c|c|c|c|}
\hline \multirow[t]{2}{*}{ Factor/ Attribute } & \multicolumn{4}{|c|}{ SECI Cluster } & \multirow[t]{2}{*}{$\mathbf{F}$} \\
\hline & $1(n=48)$ & $2(n=16)$ & $3(n=22)$ & $4(n=42)$ & \\
\hline ICT & $4.63(2,3,4)$ & $3.92(1,3,4)$ & $3.21(1,2,4)$ & $2.04(1,2,3)$ & $59.49 * * *$ \\
\hline ICT1 & $4.68(4)$ & $4.20(4)$ & $3.97(4)$ & $2.37(1,2,3)$ & $15.50 * * *$ \\
\hline ICT2 & $4.90(2,3,4)$ & $4.18(1,3,4)$ & $3.26(1,2,4)$ & $2.00(1,2,3)$ & $39.89 * * *$ \\
\hline ICT3 & $4.27(2,3,4)$ & $3.37(1,3,4)$ & $2.59(1,2,4)$ & $1.18(1,2,3)$ & $41.20 * * *$ \\
\hline ICT4 & $4.68(2,3,4)$ & $3.75(1,3,4)$ & $2.81(1,2,4)$ & $1.93(1,2,3)$ & $32.93 * * *$ \\
\hline ICT5 & $4.63(3,4)$ & $4.16(3,4)$ & $3.50(1,2,4)$ & $2.00(1,2,3)$ & $22.76^{* * *}$ \\
\hline ICT6 & $4.63(2,3,4)$ & $3.85(1,3,4)$ & $3.16(1,2)$ & $2.75(1,2)$ & $15.13^{* * *}$ \\
\hline KMR & $4.26(2,3,4)$ & $3.63(1,3,4)$ & $2.80(1,2,4)$ & $1.66(1,2,3)$ & $69.96^{* * *}$ \\
\hline KMR1 & $4.45(2,3,4)$ & $3.54(1,3,4)$ & $2.76(1,2,4)$ & $1.37(1,2,3)$ & $33.62 * * *$ \\
\hline KMR2 & $4.36(2,3,4)$ & $3.54(1,3,4)$ & $2.76(1,2,4)$ & $1.81(1,2,3)$ & $31.61 * * *$ \\
\hline KMR3 & $4.40(3,4)$ & $3.79(3,4)$ & $2.92(1,2,4)$ & $1.75(1,2,3)$ & $35.12 * * *$ \\
\hline KMR4 & $3.90(3,4)$ & $3.62(3,4)$ & $2.54(1,2,4)$ & $1.56(1,2,3)$ & $40.64 * * *$ \\
\hline KMR5 & $4.45(2,3,4)$ & $3.60(1,3,4)$ & $3.02(1,2,4)$ & $2.12(1,2,3)$ & $26.89 * * *$ \\
\hline KMR6 & $4.09(3,4)$ & $3.60(3,4)$ & $2.83(1,2,4)$ & $1.43(1,2,3)$ & $31.66^{* * *}$ \\
\hline KMR7 & $4.18(3,4)$ & $3.75(3,4)$ & $2.80(1,2,4)$ & $1.56(1,2,3)$ & $41.39 * * *$ \\
\hline
\end{tabular}

Note: SECI Cluster: 1 = Leaders, 2 = Fast Followers, $3=$ Slow Followers, $4=$ Laggards; Numbers in parentheses indicate group number from which the group is different at the significant level 0.05 (Scheffe Test). ${ }^{*} p<0.05 ;{ }^{* *} p<0.01 ; * * * p<0.001$

Finally, we examined the differences between the groups in global SCM performance. The four groups reveal significant differences in the six items. However, performance levels about the items of 'international transportation' and 'international distribution and after sales' are not significantly different between the groups because the lower two groups recorded relatively higher scores in these items compared with the other six indices, which may reflect the sampled multinationals have generally good knowledge and practices on the basic logistics activities required for international operations. Nevertheless, the overall empirical results imply that the firms effectively creating and conversing multinational business knowledge through the sub-processes of socialization, externalization, combination and internalization could achieve superior performance in the global SCM related activities. 
Table 9.

One-way ANOVA of GSCP and IBP differences between the four groups

\begin{tabular}{|c|c|c|c|c|c|}
\hline \multirow[t]{2}{*}{ Factor/ Attribute } & \multicolumn{4}{|c|}{ SECI Cluster } & \multirow[t]{2}{*}{ F } \\
\hline & $1(n=48)$ & $2(n=16)$ & $3(n=22)$ & $4(n=42)$ & \\
\hline GSCP & $4.12(2,3,4)$ & $3.64(1,3,4)$ & $3.16(1,2,4)$ & $2.33(1,2,3)$ & $27.69 * * *$ \\
\hline GSCP1 & $4.38(3,4)$ & $3.78(3,4)$ & $3.21(1,2,4)$ & $2.34(1,2,3)$ & $20.99 * * *$ \\
\hline GSCP2 & $4.14(3,4)$ & $3.57(3,4)$ & $2.80(1,2,4)$ & $1.94(1,2,3)$ & $19.19 * * *$ \\
\hline GSCP3 & $4.40(4)$ & 4.04 & 3.83 & $3.37(1)$ & $4.33 * *$ \\
\hline GSCP4 & $3.90(4)$ & $3.74(4)$ & 3.24 & $2.59(1,2)$ & $8.66^{* * *}$ \\
\hline GSCP5 & $4.04(3,4)$ & $3.51(4)$ & $3.22(1,4)$ & $2.27(1,2,3)$ & $14.58^{* * *}$ \\
\hline GSCP6 & $4.04(2,3,4)$ & $3.41(1,4)$ & $2.96(1,4)$ & $2.21(1,2,3)$ & $16.29 * * *$ \\
\hline GSCP7 & $4.04(3,4)$ & $3.65(3,4)$ & $3.11(1,4)$ & $1.95(1,2,3)$ & $21.80 * * *$ \\
\hline GSCP8 & $4.00(3,4)$ & $3.45(3,4)$ & $2.88(1,2,4)$ & $2.02(1,2,3)$ & $17.26^{* * *}$ \\
\hline
\end{tabular}

Note: SECI Cluster: 1 = Leaders, 2 = Fast Followers, 3 = Slow Followers, 4 = Laggards; Numbers in parentheses indicate group number from which the group is different at the significant level 0.05 (Scheffe Test). ${ }^{*} p<0.05 ;{ }^{* *} p<0.01 ;{ }^{* * *} p<0.001$

\section{Summary and Conclusions}

The present study examines multinational firms' knowledge management systems, knowledge creation processes and global supply chain management performance and attempts to reveal any significant linkages among the latent variables. For this research interest, most of all, we proposed 18 items to measure four types of knowledge creation processes (SECI) designed by Nonaka (1994). The measurements of 18 items were selected referring to a wealth of literature and revised reflecting the global business environment, in particular involving the global supply chain management concept. The validation of our measurement model was ensured by confirmatory factor analysis.

Utilizing the confirmed SECI model, the 128 sample companies were classified into four groups according to their levels of knowledge creation processes, which are labeled SECI leaders, SECI fast followers, SECI slow followers and SECI laggards. A series of ANOVA tests reveals that the SECI leaders have built and operated advanced knowledge management systems including information and communication technology and knowledge management rules and have recorded superior global business performance in terms of global supply chain management. The inference of this empirical test is that significant influential linkages may exist between a multinational firm's knowledge management system and knowledge creation process; and also between its knowledge creation process 
and its global supply chain management performance.

In particular, this study suggests that the creation and conversion of tacit knowledge as well as explicit knowledge can be supported by information and communication technology and then both types of knowledge may generate significant performance gaps between multinational firms. As asserted by many authors, knowledge can be a critical resource to distinguish one firm from the others, which means that multinational firms should effectively operate their knowledge management systems and continuously create and expand both explicit and tacit knowledge in order to generate outstanding performance and further their competitive advantage in the global marketplace. 


\section{Appendix: Descriptive statistics for the measurement model}

\begin{tabular}{|c|c|c|c|c|c|}
\hline Construct & Item & Minimum & Maximum & Mean & SD \\
\hline Information and & ICT1 & 1 & 5 & 3.98 & 1.25 \\
\hline Communication Technology & ICT2 & 1 & 5 & 3.73 & 1.25 \\
\hline Infrastructure (ICT) & ICT3 & 1 & 5 & 2.99 & 1.26 \\
\hline \multirow[t]{3}{*}{ (Mean: 3.57 / SD: 0.99) } & ICT4 & 1 & 5 & 3.37 & 1.26 \\
\hline & ICT5 & 1 & 5 & 3.75 & 1.30 \\
\hline & ICT6 & 1 & 5 & 3.62 & 1.16 \\
\hline Knowledge Management & KMR1 & 1 & 5 & 3.17 & 1.33 \\
\hline Rules (KMR) & KMR2 & 1 & 5 & 3.21 & 1.16 \\
\hline \multirow[t]{5}{*}{ (Mean: 3.22 / SD: 0.99) } & KMR3 & 1 & 5 & 3.35 & 1.18 \\
\hline & KMR4 & 1 & 5 & 3.06 & 1.11 \\
\hline & KMR5 & 1 & 5 & 3.37 & 1.07 \\
\hline & KMR6 & 1 & 5 & 3.16 & 1.20 \\
\hline & KMR7 & 1 & 5 & 3.24 & 1.15 \\
\hline Socialization (SECI-S) & $\mathrm{S} 1$ & 1 & 5 & 3.16 & 1.16 \\
\hline \multirow[t]{4}{*}{ (Mean: 2.97 / SD: 1.00) } & $\mathrm{S} 2$ & 1 & 5 & 2.93 & 1.18 \\
\hline & $\mathrm{S} 3$ & 1 & 5 & 2.96 & 1.11 \\
\hline & $\mathrm{S} 4$ & 1 & 5 & 2.78 & 1.07 \\
\hline & S5 & 1 & 5 & 3.00 & 1.20 \\
\hline Externalization (SECI-E) & E1 & 1 & 5 & 3.29 & 1.15 \\
\hline \multirow[t]{4}{*}{ (Mean: 3.29 / SD: 0.88) } & $\mathrm{E} 2$ & 1 & 5 & 3.56 & 1.16 \\
\hline & E3 & 1 & 5 & 2.94 & 1.24 \\
\hline & E4 & 1 & 5 & 3.31 & 1.17 \\
\hline & E5 & 1 & 5 & 3.37 & 1.02 \\
\hline Combination (SECI-C) & $\mathrm{C} 1$ & 1 & 5 & 3.38 & 1.03 \\
\hline
\end{tabular}




\begin{tabular}{|c|c|c|c|c|c|}
\hline Construct & Item & Minimum & Maximum & Mean & SD \\
\hline \multirow[t]{3}{*}{ (Mean: 3.49 / SD: 0.91) } & $\mathrm{C} 2$ & 1 & 5 & 3.51 & 1.03 \\
\hline & $\mathrm{C} 3$ & 1 & 5 & 3.58 & 1.03 \\
\hline & $\mathrm{C} 4$ & 1 & 5 & 3.49 & 1.07 \\
\hline Internalization (SECI-I) & I1 & 1 & 5 & 3.30 & 0.99 \\
\hline \multirow[t]{3}{*}{ (Mean: 3.17 / SD: 0.89) } & $\mathrm{I} 2$ & 1 & 5 & 3.09 & 0.94 \\
\hline & $\mathrm{I} 3$ & 1 & 5 & 3.11 & 1.06 \\
\hline & $\mathrm{I} 4$ & 1 & 5 & 3.17 & 1.10 \\
\hline Global Supply Chain & GSCP1 & 1 & 5 & 3.51 & 1.03 \\
\hline Performance (GSCP) & GSCP2 & 1 & 5 & 3.21 & 1.20 \\
\hline \multirow[t]{6}{*}{ (Mean: 3.40 / SD: 0.82) } & GSCP3 & 1 & 5 & 3.95 & 0.95 \\
\hline & GSCP4 & 1 & 5 & 3.46 & 1.00 \\
\hline & GSCP5 & 1 & 5 & 3.35 & 0.97 \\
\hline & GSCP6 & 1 & 5 & 3.22 & 0.99 \\
\hline & GSCP7 & 1 & 5 & 3.33 & 1.05 \\
\hline & GSCP8 & 1 & 5 & 3.18 & 1.07 \\
\hline
\end{tabular}




\section{References}

Anderson, J.C. and Gerbing, D.W. (1988), Structural equation modeling in practice: A review and recommended two-step approach, Psychological Bulletin 103(3): 411-423.

Antonelli, C. (1997), New information technology and the knowledge-based economy: The Italian Evidence. Review of Industrial Organization 12(4): 593-607.

Armstrong, J. S. and Overton, T. S. (1977), Estimating Nonresponse Bias in Mail Surveys. Journal of Marketing Research 14(3): 396-402.

Bagozzi, R.P. and Phillips, L.W. (1982), Representing and testing organizational theories: A holistic construal, Administrative Science Quarterly 27: 459-489.

Bartlett, C. A. and Ghoshal, S. (1998), Managing Across Borders: The Transnational Solution (2nd), Harvard Business School Press

Bolisani, E. and Scarso, E. (1999), Information technology management: A knowledge-based perspective, Technovation 19: 209-217.

Choi, B., Poon, S. K. and Davis, J. G. (2008), Effects of knowledge management strategy on organizational performance: A complementarity theory-based approach. Omega, The International Journal of Management Science 36(2): 235-251.

Churchill Jr., G.A. (1979), A paradigm for developing better measures of marketing constructs, Journal of Marketing Research, 16(1): 64-73.

Davenport, T. H., Jarvenpaa S. L. and Beers, M. C. (1996), Improving knowledge work processes. In: Sloan Management Review, 37(4): 53-65.

Davenport, T. H. and Prusak, L. (1998), Working knowledge: How organizations manage what they know. Harvard Business School Press, Boston.

Demarest, M. (1997), Understanding Knowledge Management, Long Range Planning 30(3): 374-384.

Drucker, P. F. (1993), Post-capitalist Society, New York: Butterworth Heineman.

Hair, J.F., Black, W.C., Babin, B.J. and Anderson, R.E. (2010), Multivariate Data Analysis $\left(7^{\text {th }}\right.$ ed), Pearson Prentice Hall.

Hamel, G. and Prahalad, C. K. (1994), Competing for the future. Harvard Business Review 72(4): 122-128. 
Hendricks, P. H. J. and Vriens, D. J. (1999), Knowledge-based systems and knowledge management: Friends or Foes? Information and Management 35: 113-125.

Hill, C. W. L. (2009), Global Business Today (6th), McGraw-Hill International Press.

Holsapple, C. W. and Singh, M. (2001), The knowledge chain model: Activities for competitiveness, Expert Systems with Applications 20: 77-98.

Hsieh, P. J., Lin, B. and Lin, C. (2009), The construction and application of knowledge navigator model (KNM): An evaluation of knowledge management maturity, Expert Systems with Applications, 36: 4087-4100.

Hsieh, P. J., Lin, B. and Lin C. (2009), The construction and application of knowledge navigator model (KNMTM): An evaluation of knowledge management maturity, Expert Systems with Applications 36: 4087-4100.

Johannessen, J.-A., Olaisen, J. and Olsen, B. (2001), Mismanagement of tacit knowledge: The importance of tacit knowledge, the danger of information technology and what to do about it, International Journal of Information Management 21:3-20.

Knapp, E. M. (1998), Knowledge management, Business and Economic Review 44(4): 3-6.

Lee, H. and Choi, B. (2003), Knowledge management enablers, processes and organizational performance: An integrative view and empirical examination, Journal of Management Information Systems 20(1): 179-228.

Leonard, D. and Sensiper, S. (1998), The role of tacit knowledge in group innovation, California Management Review 40(3): 112-132.

Millar, J., Demaid, A. and Quintas, P. (1997), Trans-organizational innovation: A framework for research, Technology Analysis \& Strategic Management 9: 399-418.

Nelson, R. R. and Winter, S. G. (1982), An Evolutionary Theory of Economic Change, Cambridge, MA: Harvard University Press.

Nonaka, I. (1994), A Dynamic Theory of Organizational Knowledge Creation, Organization Science 5(1): 14-37.

Nonaka, I. and Takeuchi, H. (1995), The Knowledge-creating Company, Oxford University Press, Oxford.

Plessis, M. D. (2005), Drivers of knowledge management in the corporate environment, International Journal of Information Management 25(3): 193-202.

Polanyi, M. (1967), The Tacit Dimension, Doubleday Anchor, Garden City, NY.

Porter, M. E. (1980), Competitive Strategy: Techniques for Analyzing Industries and 
Competitors, New York: Free Press.

Porter, M. E. (1985), Competitive Advantage, The Free Press.

Sher, P. J. and Lee, V. C. (2004), Information technology as a facilitator for enhancing dynamic capabilities through knowledge management, Information Management 41: $933-945$.

Steiger, J. H. (1990), Structural model evaluation and modification: An interval estimation approach, Multivariate Behavioral Research 25 (2): 173-180.

Stewart, T. A. (1997), Intellectual Capital: The New Wealth of Organizations, London: Doubleday.

Szulanski, G. (1996), Exploring internal stickiness: Impediments to the transfer of best practice within the firm, Strategic Management Journal 17(winter special issue): 27-43.

Sher, P. J. and Lee, V. C. (2004), Information technology as a facilitator for enhancing dynamic capabilities through knowledge management, Information \& Management 41: 933-45.

Teece, D. J., Pisano, G. and Schuen, A. (1997), Dynamic capabilities and strategic management, Strategic Management Journal 18(7): 509-533.

Vaccaro, A, Veloso, F. and Brusoni, S. (2009), The impact of virtual technologies on knowledge-based processes: An empirical study, Research Policy 38: 1278-1287.

Yang, C-C., Marlow, P. B. and Lu, C-S. (2009), Knowledge management enablers in liner shipping, Transportation Research Part E 45:893-903. 